\title{
SEAWEED BUSINESS DEVELOPMENT STRATEGY IN BUTON REGENCY, SOUTHEAST SULAWESI OF INDONESIA
}

\author{
Darmi ${ }^{*}$, Hasbullah Rokhani, Jahroh Siti \\ School of Business, Bogor Agriculture University, Indonesia \\ *E-mail: darmibinhamid@gmail.com
}

\begin{abstract}
Seaweed is a type of superior aquaculture commodity in Buton Regency. Seaweed has the potential to develop seaweed businesses with high economic value. This study aims to analyze: 1) What factors influence the development of seaweed business in Buton Regency; 2) Alternative strategies for developing seaweed business in Buton Regency; 3) Priority strategies and managerial implications for enhancing seaweed business development in Buton Regency. This study used descriptive quantitative and qualitative approaches. Data analysis techniques used are Internal Factor Evaluation (IFE), External Factor Evaluation (EFE), Strength Weakness Opportunity Threat (SWOT), and Quantitative Strategy Planning Matrix (QSPM). The results of this study indicate that the IFE analysis, the internal environmental factors that gave influence is a superior cultivation commodity as the main factor of strength and limited knowledge of human resources in processing seaweed yield as the main factor of weakness. External environmental factors that gave influence are the demand for large seaweed markets as a major factor in the opportunities and ice-ice disease as a major factor of threat. The priority strategy that can be done by the Buton Regency government in increasing seaweed business with the expansion of seaweed cultivation areas. This is used as a priority strategy because there are still many potential areas for seaweed cultivation that have not been cultivated so that with the increase in seaweed cultivation area, seaweed production is expected to increase.
\end{abstract}

\section{KEY WORDS}

Superior commodities, priority strategy, business, seaweed.

Seaweed is a biological resource that is very abundant in Indonesian waters which is a potential aspect to be developed, especially in the food, beverage and cosmetic industries. The function of seaweed as a raw material for various processed products of high economic value for both food and non-food purposes makes many seaweed cultivated and traded in the local and international markets (Sri Luhur et al. 2012). The types of seaweed that are abundant in Indonesian waters are Gracilaria, Gelidium, Eucheuma, Hypnea, Sargasum and Tubrinaria (Wijayanto et al. 2011). The area of the seaweed habitat in Indonesia alone reached 1.1 million hectares (BPS 2016). Furthermore, the indicative area of land that can be used for the cultivation of Indonesian seaweed commodities reaches 769,452 ha. Of that amount, only around $50 \%$ or an area of 384,733 ha is effectively utilized, and will continue to be utilized so that the 2019 production target of 19.5 million tons can be achieved (KKP 2015). This shows that the great potential of Indonesian seaweed is to be developed and become a superior product of Indonesian export commodities. This strategy step is a very important part, considering the data of seaweed-producing regions with great potential to be developed, as shown in Table 1.

In Table 1, can be seen that seaweed cultivation production in Indonesian provinces in 2011-2015 tends to increase. South Sulawesi province is the largest seaweed producing province in 2015. In 2015 the production of seaweed cultivation in South Sulawesi province reached 2,411,124 tons, an increase of $15,4 \%$ from 2014 of 2,087,841 tons, followed by East Nusa Tenggara (2,283,331 tons), Central Sulawesi (1,362,812 tons), West Nusa Tenggara $(937,463$ tons), and Southeast Sulawesi $(915,895$ tons). In this data it is clear that Sulawesi Island is the highest producer of seaweed and it is very important to develop it. 
Table 1 - Provinces producing seaweed in Indonesia 2011-2015

\begin{tabular}{llllllll}
\hline \multirow{2}{*}{ No } & \multirow{2}{*}{ Province } & \multicolumn{2}{l}{ Seaweed (Ton) } & & \multicolumn{2}{l}{ Increase } \\
\cline { 2 - 6 } & & 2011 & 2012 & 2013 & 2014 & 2015 & Average (\%) \\
\hline 1 & South Sulawesi & $1,024,302$ & $1,480,712$ & $1,661,335$ & $2,087,841$ & $2,411,124$ & 24,48 \\
2 & East Nusa Tenggara & 377,2 & 398,736 & $1,846,334$ & $1,966,255$ & $2,283,331$ & 97,84 \\
3 & Central Sulawesi & 734,381 & 891,381 & $1,233,058$ & $1,137,030$ & $1,362,812$ & 17,94 \\
4 & West Nusa Tenggara & 277,7 & 451,031 & 599,1 & 749,141 & 937,463 & 36,36 \\
5 & Southeast Sulawesi & 586,965 & 639,192 & 917,363 & 956,017 & 915,895 & 13,11 \\
\hline
\end{tabular}

Source: Directorate General of Aquaculture KKP (2016).

Table 1 shows that the highest amount of seaweed production in Sulawesi is in South Sulawesi. Even so, the province of Southeast Sulawesi is one of the provinces that has lower seaweed production than other provinces in the Sulawesi Islands. This province has the widest land area among the other provinces which is 54,770 hectares (KKP 2016). The yield of seaweed produced is dominated by the type of Kappaphycus alvarezii (cottoni). Seaweed usually grows well in the dry season, on the contrary it grows slowly in the rainy season (Arisandi A et al. 2013). According to interviews with local authorities and farmers in Buton Regency, Southeast Sulawesi, this type of cottoni seaweed is the easiest to cultivate and has a high price. Although the area of seaweed cultivation is extensive, the area is only around $50 \%$ or 27,385 hectares are used for seaweed cultivation. One of the most potential regencies for developing seaweed cultivation is in Buton Regency, as shown in Figure 1.

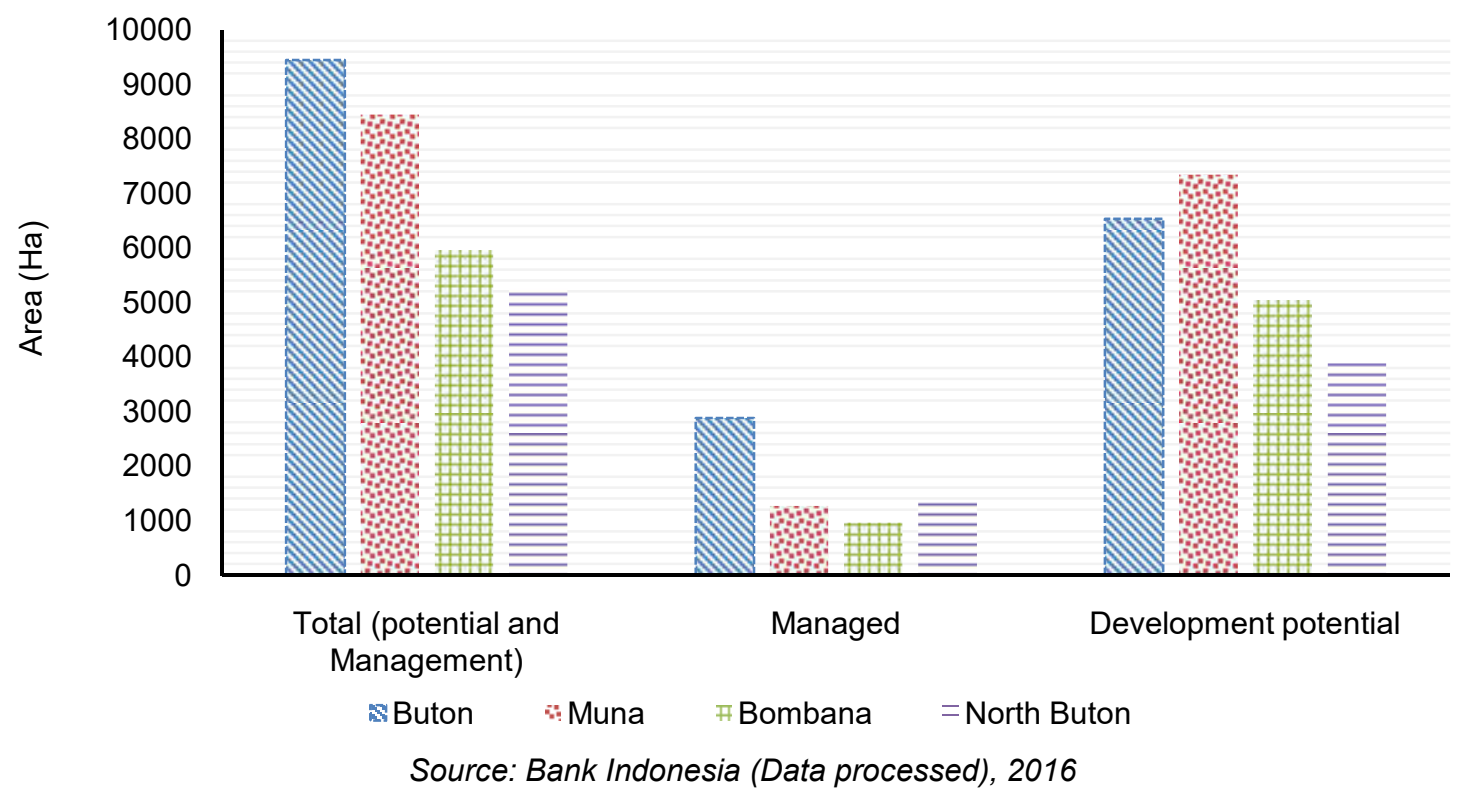

Figure 1 - Extent of seaweed cultivation in four Buton Regencies in Southeast Sulawesi Province (in hectares)

In Figure 1 can be seen that the potential of seaweed to be managed in Buton Regency is very high, that is 9,825 hectares. This is far from the potential for development carried out by the local government. Thus it is very important to develop a seaweed business strategy in Buton Regency.

Seeing the role of Buton Regency in the contribution of seaweed has been recognized nationally and internationally, but it is still necessary to increase the seaweed processing industry in the regions and domestically. So that the industry and the results of processing seaweed can be sold both at domestic and international. If that happens then the production in the following year must be above 5,000 per ton so that domestic and foreign supplies are not hampered due to their production.

This certainly needs special attention and a strategy for developing a planned seaweed business. In addition, the price bought by collectors from farmers is still very low, which 
causes farmers to feel disadvantaged in Buton Regency. In addition, the purchase price of all types of seaweed from the farmers is valued at the same price without seeing the quality and type of seaweed by the collectors. In Figure 2 shows the development of seaweed prices at the national level, collectors, and farmers from 2013 to 2017 in Buton Regency.

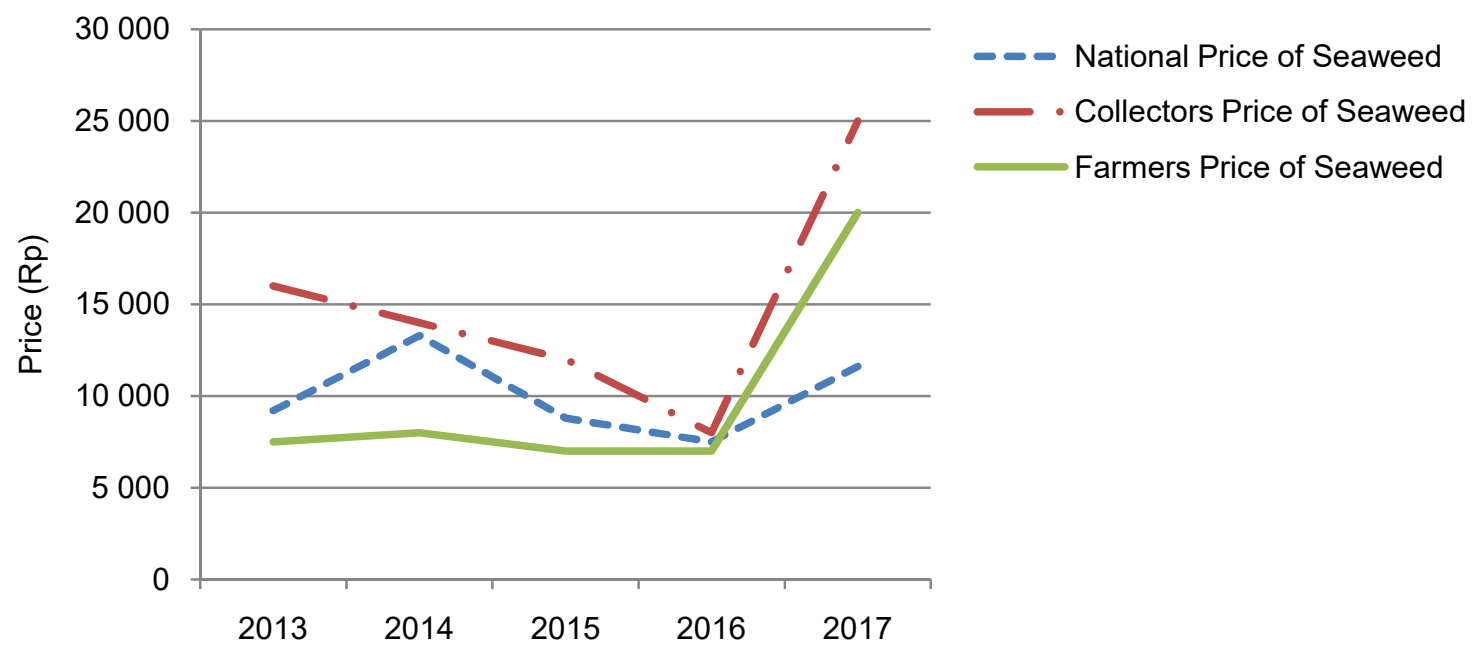

Source: Fisheries and Maritime Office of Buton Regency (Data processed), 2017

Figure 2 - Seaweed prices in Buton Regency

Figure 2 shows a very volatile price difference both at the level of farmers, collectors and at the national level. This happens because the farmers who do not know the up-to-date price differences in the market/Farmer Benchmark Price. Thus the price of seaweed is still affected by the season and the respective regions of Hikmayani et al. (2007). This indirectly provides greater benefits for collectors, but disadvantages the farmers because farmers should receive higher prices from collectors because the quality of seaweed produced by farmers is classified as high quality seaweed and relatively high prices of processed seaweed. It was seen in 2016 the price of cottoni type seaweed was at a low point, because farmers had been tied to collectors or had debts with collectors, so the bargaining position of farmers was so low to collectors.

Based on the background analysis that has been described, it can be drawn three main issues of the problems that occur, namely 1) minimum price and capital transparency among farmers, as well as unclear regulations regarding the standard price of seaweed from the government; 2) inadequate seaweed processing systems and low human resources; 3) inadequate infrastructure in post-harvest activities and government policies related to the development of seaweed business. follows:

Based on exposure to the background and problem, the objectives of this study are as

- Identify environmental factors that influence the development of seaweed business in Buton Regency, Southeast Sulawesi;

- Formulate alternative development strategies for seaweed business in Buton Regency, Southeast Sulawesi;

- Formulate strategic priorities and managerial implications to improve the development of seaweed business in Buton Regency, Southeast Sulawesi.

\section{METHODS OF RESEARCH}

This research was conducted from January 2018 to February 2018 located in the province of Buton Regency, Southeast Sulawesi. The data used in this study is in the form of primary and secondary data. Primary data is obtained from the results of questionnaires and in-depth interviews with selected respondents. Secondary data were obtained from literature 
studies derived from journals, books, archives of the Buton Marine and Fisheries Office, Central Agency on Statistics, and previous research. The data sources in this study can be seen in Table 2.

Table 2 - Data sources

\begin{tabular}{llll}
\hline No & Data Type & Data Retrieval Techniques & Data Source \\
\hline 1 & $\begin{array}{l}\text { Primary Data } \\
\text { External internal factors that influence the } \\
\text { development of seaweed agribusiness in } \\
\text { Buton Regency }\end{array}$ & Questionnaire Interview & Seaweed Businessman \\
& & Marine and Fisheries Office \\
& Secondary Data & Seaweed Expert & Farmer \\
\hline 2 & Other supporting data & Content Analysis & Business Report Data \\
& (literature review) & Government Data \\
& & Research Publication \\
& & Internet and journal \\
\hline
\end{tabular}

The analysis used in this study is qualitative analysis that is quantified by approaches to strategic management concepts from scientific literature, opinions of experts, and opinions of practitioners who have empirical experience in their fields of expertise. The qualitative method used is descriptive analysis, can be seen in Table 3. This analysis is used to describe an in-depth description of matters related to research object.

Table 3 - Data processing and analysis techniques

\begin{tabular}{|c|c|c|c|}
\hline No & Analysis Process & $\begin{array}{l}\text { Analysis } \\
\text { Tool }\end{array}$ & Output \\
\hline 1. & $\begin{array}{l}\text { Analysis of the existing strategy of } \\
\text { seaweed business }\end{array}$ & IFE/EFE & $\begin{array}{l}\text { Information on the issue of seaweed business } \\
\text { development strategies in Buton Regency }\end{array}$ \\
\hline 2. & Formulation of alternative strategies & SWOT & $\begin{array}{l}\text { Alternative strategy formulation } \\
\text { Prioritized strategies to be applied in the }\end{array}$ \\
\hline 3. & Determination of strategic priorities & QSPM & $\begin{array}{l}\text { development of seaweed businesses in Buton } \\
\text { Regency }\end{array}$ \\
\hline
\end{tabular}

\section{RESULTS AND DISCUSSION}

Factors were distinguished by internal and external factors, so that internal environmental conditions can be identified in the form of strengths and weaknesses and external environmental conditions in the form of opportunities and threats, for development of seaweed business in Buton Regency.

Internal Factor Evaluation (IFE) Analysis. IFE matrix analysis is the result of internal factors identification in the form of strengths and weaknesses of Buton Regency from the analysis of internal environmental aspects that have been explained previously, this IFE analysis can be seen in Table 4.

Table 4 - Results of IFE matrix analysis in seaweed development strategies in Buton Regency

\begin{tabular}{llll}
\hline Strategic Factors & Integrity & Rate & Score \\
\hline Strength & & & \\
\hline Superior cultivation commodities & 0.1117 & 4 & 0.4466 \\
High production level & 0.1068 & 4 & 0.4272 \\
Potential resources & 0.1068 & 4 & 0.4272 \\
The farmers are able to produce seeds independently & 0.1019 & 3 & 0.3058 \\
The quality of raw materials has met national standards & 0.1068 & 4 & 0.4272 \\
\hline Weakness & & & \\
\hline Unable to meet the demand & 0.1019 & 2 & 0.2039 \\
Seaweed productivity is not optimal & 0.1068 & 1 & 0.1068 \\
The absence of a standard price for seaweed & 0.0971 & 1 & 0.0971 \\
The quality of seaweed doesn't meet export standards & 0.0922 & 2 & 0.1845 \\
Limited knowledge of human resources in processing seaweed products & 0.0777 & 2 & 0.1553 \\
\hline Total & 1 & & 2.7427 \\
\hline
\end{tabular}


In Table 4, it can be seen that the IFE matrix obtained a total score 2.7427 of Buton Regency in the development of seaweed. With a total weight score above 2.5 indicating that the internal position of Buton Regency is sufficient to overcome the existing weaknesses with its strength. Furthermore, the results of the IFE matrix show that the strength factor that has a large influence on Buton Regency is a superior cultivation commodity with (score 0.4466). While the main weakness factor of Buton Regency is Buton Regency has not been able to meet the existing demand (score 0.2039).

External Factor Evaluation (EFE) Analysis. EFE matrix analysis of seaweed development in Buton Regency is the result of identification of external factors in the form of opportunities and threats that influence the development of seaweed, as shown in Table 5.

Table 5 - Results of EFE matrix analysis in seaweed development strategies in Buton Regency

\begin{tabular}{|c|c|c|c|}
\hline Strategic Factors & Integrity & Rate & Score \\
\hline \multicolumn{4}{|l|}{ Opportunity } \\
\hline High demand of seaweed market & 0.1214 & 3 & 0.3641 \\
\hline Seaweed derivative products are so diverse & 0.1117 & 1 & 0.1117 \\
\hline Potential area of seaweed cultivation that has not been cultivated & 0.1165 & 2 & 0.2330 \\
\hline Government support in developing the integration of the seaweed industry & 0.1068 & 3 & 0.3204 \\
\hline \multicolumn{4}{|l|}{ Threat } \\
\hline Uncertain climate conditions & 0.1068 & 3 & 0.3204 \\
\hline Government policies related to taxes & 0.0825 & 2 & 0.1650 \\
\hline No infrastructure is available regarding post-harvest activities & 0.0777 & 1 & 0.0777 \\
\hline Ice-ice disease & 0.1214 & 4 & 0.4854 \\
\hline Blooming algae & 0.0922 & 4 & 0.3689 \\
\hline The threat of seaweed delisting by the United States & 0.0631 & 1 & 0.0631 \\
\hline Total & 1 & & 1.4806 \\
\hline
\end{tabular}

Based on the results of the EFE matrix in Table 5, a total score of 1.4806 was obtained. With a total weight score below 2.5 indicating that the Buton Regency government has not been able to fully respond well to external factors by utilizing opportunities to overcome existing threats. This means that the Buton Regency government must make improvements through optimal utilization of existing opportunities. Furthermore, the main opportunity for developing seaweed business in Buton Regency is the demand for a large seaweed market with a score of 0.3641 . While the main threat of seaweed business development is ice-ice disease with a score of 0.4854 .

SWOT Analysis. Based on the analysis of the internal and external environment carried out by identifying environmental factors in the seaweed business development strategy in the Buton regency through the process of filling out questionnaires by the speakers. Then formulate strategic alternatives through Strength-Opportunity (SO), Strength-Threat (ST), Weakness-Opportunity (WO) and Weakness-Threat (WT) analysis. Based on SWOT matrix analysis, alternative strategies can be formulated as follows:

Strength-Opportunity Strategy (S-O). This S-O strategy is carried out based on the Buton regency governance strategy of how to use the owned power to take advantage of the opportunities that exist in developing seaweed business. In this strategy, there are two alternative strategies, those are:

- Expansion of seaweed cultivation area (S1, S2, O3). This strategy is considered very appropriate to be implemented by the Buton Regency government to develop superior seaweed commodities. This is because the increase in the amount of seaweed production must be balanced by the expansion of seaweed area.

- Increasing institutional role in each stakeholder of seaweed (farmers, distribution, marketing and government) (S4, S3, O4). This strategy step aims to strengthen the cooperative relationship between stakeholders and their responsibility to jointly improve the level of welfare of the Buton Regency through optimizing the productivity of seaweed business. 
Strength-Threat Strategy (S-T). This strategy is the use of the strength of the Buton Regency government in avoiding external threats. This strategy produces two alternative strategies.

- Evaluation and analysis of risk management of seaweed cultivation in Buton Regency (S1, S2, S3, S4, S5, T1, T4, T5). This strategy generally aims to control the output that has been targeted at the collaborations carried out by the Buton Regency government.

- Improvement of infrastructure and system implementation of seaweed industry in Buton Regency (S3, S4, T2, T3). Infrastructure and all supporting administrative systems are essential conditions for developing and increasing seaweed commodities. This means the opportunity to disclose seaweed exports and imports in Buton Regency.

Weakness-Opportunity Strategy (W-O). This W-O strategy is a strategy to improve internal weaknesses by utilizing external opportunities. There are two alternative strategies, those are:

- Enhancement of productivity, quality and competitiveness of seaweed (W1, W2, W3, W4, O1, O3, O4). The development of seaweed commodity competitiveness through increasing productivity and quality of seaweed products, will certainly be the right step.

- Intensive government participation in HR development, guidance and training (W5, W4, O2, O4). Government involvement in increasing the productivity of seaweed must be supported by intensive training, counseling and guidance for seaweed farmers. The value of this education can increase the knowledge and skills of farmers and the community.

Weakness-Threat Strategy $(W-T)$. The W-T strategy is an alternative strategy aimed at reducing internal weaknesses and avoiding external threats. This strategy persists by reducing weaknesses and avoiding threats.

- Application of appropriate technology, in improving risk management of seaweed cultivation (W2, W4, W5, T1, T4, T5). Appropriate technology and innovation are the key to a successful business in this era of technology and information. By utilizing seaweed processing technology and its derivative products, it will accelerate the increase in seaweed business in Buton Regency.

- Strengthening the market price strategy (W3, T2). The government needs to encourage the establishment and strengthening of seaweed prices from upstream to downstream. This is considered important to maintain the stability of seaweed prices and improve the welfare of seaweed farmers.

QSPM Analysis. Decision making in this research used the Quantitative Strategy Planning Matrix (QSPM) analysis tool. In the final stage of strategy formulation development is to make decisions (decision stage) using the QSPM matrix. The results of the QSPM matrix analysis can be seen in Table 6 .

Table 6 - Alternative strategies of QSPM matrix results

\begin{tabular}{|c|c|c|c|}
\hline No & Alternative Strategy & TAS & $\begin{array}{l}\text { Priority } \\
\text { Strategy }\end{array}$ \\
\hline 1 & Expansion of seaweed cultivation area & 3.18 & 1 \\
\hline 2 & $\begin{array}{l}\text { Increased institutional role in each stakeholder of seaweed } \\
\text { (farmers, distribution, marketing and government) }\end{array}$ & 3.12 & 2 \\
\hline 3 & Strengthening the market price strategy & 3.02 & 3 \\
\hline 4 & Increased productivity, quality and competitiveness of seaweed & 2.90 & 4 \\
\hline 5 & Intensive government participation in developing human resource development and training & 2.83 & 5 \\
\hline 6 & Evaluation and analysis of risk management of seaweed cultivation in Buton Regency & 2.67 & 6 \\
\hline 7 & Application of appropriate technology, in increasing risk management of seaweed cultivation & 2.61 & 7 \\
\hline 8 & $\begin{array}{l}\text { Infrastructure improvement and system implementation in the seaweed industry } \\
\text { in Buton Regency }\end{array}$ & 2.26 & 8 \\
\hline
\end{tabular}


Table 6 above shows that an alternative strategy for developing seaweed business that has the highest priority is the strategy of expanding the area of seaweed cultivation (weight 3.18).

\section{MANAGERIAL IMPLICATIONS}

Based on the analysis of internal-external factors, SWOT matrix and QSPM matrix, alternative strategies for Buton Regency government were obtained to develop seaweed businesses to prosper the people. The managerial implications steps that can be applied by the Buton Regency government are as follows:

Expansion of seaweed cultivation area. The implication programs run by the Buton Regency government collaborating with stakeholders to open up land areas for seaweed cultivation by exempting potential lands. With this step, through cooperation with stakeholders, Buton Regency Government must issue investment funds to expand the cultivation area of seaweed business. The source of this investment fund can be sourced from the regional budget of Buton Regency as well as from outside investment, one of which is from the Japanese company side which in its $\mathrm{MoU}$ is committed to developing seaweed cultivation in Buton Regency.

Increased institutional role in each stakeholder of seaweed (farmers, distribution, marketing and government). This strategy is focus on prioritizing the continuity role of collaboration among stakeholders through institutions. The first program that is very important to do is formally form a cooperative institution. The existence of cooperatives for farmers in each region or group of seaweed farmers will certainly accelerate all obstacles faced by seaweed farmers, including the transparency of seaweed prices at the farmer level. With the existence of cooperatives, seaweed farmers will get official price transparency by the government and make the members of the seaweed farmers group prosperous. The second program is a program to improve infrastructure support for both import and export activities, namely in the form of access to roads, ports, markets and infrastructure in the form of administrative offices for seaweed business managers in Buton Regency. Furthermore, the third program is providing credit or capital loans to potential seaweed farmers. This credit must be followed by a low interest rate. This is important to do because all this time the farmers' capital has relied on the bank, and from money lenders with high interest. By opening these three priority programs, in the next five or ten years it will certainly make seaweed commodities superior and become a source of Indonesian seaweed exports.

Strengthening the market price strategy. The managerial implication program for strengthening the right market price by the Buton Regency government is the determination of a standard price for seaweed. The basis for determining this one price comes from the central government. With the application of one price, it is expected that seaweed farmers, wholesalers, and entrepreneurs who play a role in it contribute to advancing the seaweed business for mutual welfare. Furthermore, to strengthen the market price strategy for all seaweed products, we must pay attention to the Segmentation, Targeting, Positioning (STP) strategy.

\section{CONCLUSION AND RECOMMENDATIONS}

Based on the analysis of the results and the discussion that has been described, the following is a conclusion of this research:

The internal environmental factors that influence the development of seaweed business in Buton Regency, that seaweed is a superior cultivation commodity and the highest production of cultivation commodities as the main factor of strength, and productivity is not optimal as the main factor of weakness. The external environmental factors that influence the development of seaweed business in Buton Regency are the demand for large seaweed markets as the main factors of opportunity and ice-ice disease as the main factor of threat.

Alternative strategies in increasing seaweed business in Buton Regency by notice the existing strategic factors such as Strength-Oppotunity (SO), Strength-Threats (ST), 
Weakness-Opportunity (WO) and Weakness-Threat (WT) factors such as 1). Expansion of seaweed cultivation area, 2). Increasing institutional role in each stakeholder of seaweed (farmers, distribution, marketing and government), 3). Strengthening the market price strategy, 4). Enhancement of productivity, quality and competitiveness of seaweed, 5). Intensive government participation in HR development, guidance and training, 6). Evaluation and analysis of risk management of seaweed cultivation in Buton Regency, 7). Application of appropriate technology, in improving risk management of seaweed cultivation, 8). Improvement of infrastructure and system implementation of seaweed industry in Buton Regency.

The priority strategy that can be done by the Buton Regency government in improving seaweed business is the expansion of seaweed cultivation areas. This is used as a priority strategy because there are still many potential areas of seaweed cultivation that have not been cultivated so that with expanding the area of seaweed cultivation, seaweed production is expected to increase.

\section{RECOMMENDATIONS}

Based on the analysis that has been conducted to answer the research objectives, such as identifying environmental factors that influence the seaweed business development strategy in Buton Regency, formulating alternative seaweed business development strategies, as well as formulating strategic priorities and managerial implications to improve the development of seaweed in Buton Regency, it can be concluded that important recommendations in this research are as follows:

- Buton Regency Government must utilize the power of abundant natural resource potential to increase the potential of seaweed cultivation in Buton Regency;

- Buton Regency Government must cooperate with several strategic parties, such as stakeholders by establishing joint ventures such as cooperatives;

- Future research can further examine the potential of other aquaculture commodities in Buton Regency. This is important because the hidden potential in Buton Regency is not only seaweed commodities, other commodities such as lobster, groper fish, mabe pearl and other marine commodities that have the potential to be developed in Buton Regency.

\section{REFERENCES}

1. Arisandi A, Farid A, Wahyuni A, Rokhmaniati S. 2013. Dampak Infeksi Ice-Ice dan Epifit terhadap Pertumbuhan Eucheuma Cottani. Jurnal IImu Kelautan Maret 2013 Vol. 18(1): 1-6.

2. [BPS] Badan Pusat Statistik. 2016. Statistik Sumber Daya Laut dan Pesisir. Jakarta (ID): Badan Pusat Statistik.

3. Hikmayani Y, Aprilliani T, Zamroni A. 2007. Analisis pemasaran rumput laut di wilayah potensial di Indonesia. Sosial Ekonomi Kelautan dan Perikanan. 2(2):159-175.

4. Sri Luhur E, Witomo MC, Firdaus M 2012. Analisa Daya Saing Rumput Luat di Indonesia (Studi Kasus : Kabupaten Konawe Selatan, Sulawesi Tenggara. Balai Besar Penelitian Sosial Ekonomi Kelautan dan Penelitian. J. Sosek KP Vol. 7 No.

5. Wijayanto T, Hendri M, Aryawati R. 2011. Studi pertumbuhan rumput laut eucheum cootonii dengan berbagai metode penanaman yang berbda di perairan Kalinda Lampung Selatan. Masparin. 3:51-57. 